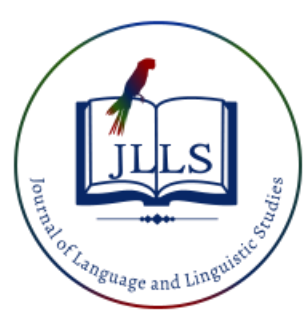

ISSN: $1305-578 \mathrm{X}$

Journal of Language and Linguistic Studies, 17(2), 816-827; 2021

\title{
Foreign language teacher students' attitudes toward reading: Implications for
}

\section{language teacher education}

\author{
Aysel Deregözü al iD, Bilal Üstün ${ }^{\text {b }}$ iD \\ ${ }^{a}$ Inonu University, Malatya, Turkey \\ APA Citation: \\ ${ }^{b}$ Nevşehir Hacı Bektaş Veli University, Nevşehir, Turkey
}

Deregözü, A., \& Üstün, B. (2021). Foreign language teacher students' attitudes toward reading: Implications for language teacher education. Journal of Language and Linguistic Studies, 17(2), 816-827. Doi: 10.52462/j1ls.57

Submission Date:21/03/2021

Acceptance Date:30/05/2021

\begin{abstract}
The study investigates the reading attitude of language teacher students and how reading attitude differs in terms of the variables gender, major, education experience, and level of proficiency. In the study, the Reading Attitude Scale was used which is developed to measure the reading attitudes of teacher students. The scale is implemented to language teacher students studying foreign language teaching at a public university in Turkey. The data were collected from language teacher students with two majors (English and German) during the academic year 2020 - 2021. The data were analysed by using the PASW Statistics 18.00 program. As the data showed normal distribution, the parametric statistical analyses independent - samples t-Test and one-way ANOVA were used. The results revealed that language teacher students' reading attitude differs in terms of the variables gender, major and education experience. But in terms of the level of proficiency, there were significant differences just in the category personal and social development. In the other categories, there were no significant differences. Based on the study findings it is suggested to support learners with extracurricular reading activities and materials, which applies to their interests and their preferences of reading texts in a foreign language.
\end{abstract}

Keywords: reading; reading attitude; language learning; language teacher

\section{Introduction}

In the development of reading skills, a positive attitude towards reading is regarded to be one of the prerequisites (Sarar Kuzu \& Dogan, 2015). The role of the attitude of readers is important for two principal reasons: "First, attitude may affect the level of ability ultimately attained through its influence on such factors as engagement and practice. Second, even for the fluent reader, poor attitude may occasion a choice not to read when other options exist, a condition now generally known as aliteracy" (McKenna, Kear, \& Ellsworth, 1995, p.934). Hence, attitude towards reading has an impact both on practice and the choice to read which may also influence reading achievement. Nevertheless, research findings indicate a consistent link between attitude and achievement (McKenna \& Kear, 1990). The study designed to determine the structural relationships between reading attitude,

\footnotetext{
${ }^{1}$ Corresponding author.

E-mail address: aysel.deregozu@inonu.edu.tr
} 
comprehension, and academic achievement conducted by Bastug (2014) indicated that there were a direct and positive structural correlations between reading attitudes, reading comprehension, and academic achievement. It is emphasized that "Readers with a positive attitude to reading read more, and those who read a lot will be more successful in reading" (Bastug, 2014, p.941).

In this regard, attitude towards reading has an outstanding role not just for reading in general, but also specifically for language learning. It is stated that in language learning, attitude is one of the main factors that affect the process of reading in foreign and second language learning (Day \& Bamford, 1998, cited in Marpaung, 2020). Thus, the development of reading skills in a foreign language is dependent on a positive attitude towards reading. It is emphasized, "While the learners' negative attitudes and feelings pose an obstacle to progress, positive emotions and attitudes make language learning far more effective and enjoyable" (Merisuo-Storm, 2007; Oxford, 1990, cited in Özender, 2015, p.723). Hence, as an affective factor, attitude plays a key role in the acquirement of reading skills in a foreign language.

Yet, despite the great amount of research accumulated in the field of the second language (L2) reading, the affective domain of reading has received much less attention than the cognitive domain (Yamashita, 2004). As reading attitude affects the development of reading skills in a foreign language, it is of crucial importance that language learners possess positive attitudes towards reading. A positive attitude towards reading is also crucial for language teacher students, as they are prospective language teachers. The importance lays not just on academic reasons, where a positive attitude towards reading favours academic achievement, but also on the fact that teachers may act as a role model to their students. In this context, this study aims to contribute to researches in general in the field of affective domains and specifically attitude towards reading in language teacher education.

\subsection{Literature review}

\subsubsection{Reading attitude}

An attitude is described as a "Relatively enduring organization of beliefs around an object or a situation, predisposing one to respond in some preferential manner." (Rokeach 1968, cited in Smith, 1971, p.82), as a "Psychological tendency that is expressed by evaluating a particular entity with some degree of favour or disfavour" (Eagly \& Chaiken, 1993, p. 1) or "an evaluative reaction to some referent or attitude object, inferred on the basis of the individual's beliefs or opinions about the referent" (Gardner, 1985; cited in Alkhannani, 2016, p.70). Bastug (2014) defines it "as a cognitive manner that has emotional and sentimental side and affects on the person's decision regarding doing something or not" (p.932). Out of these definitions, attitude can be specified as beliefs and evaluative reactions towards an entity. According to Smith (1971) attitude encompasses four components: Cognitive, affective, evaluative, and behavioral. The cognitive component is related with the perception of the concept or situation. The affective components are feelings, which arise about the cognitive element. The evaluative component is the appraisal of these feelings into the categories good or bad and the behavioral component is the translation of these evaluations into acts (p.82 -83).

In the context of reading attitude, the favour or disfavour towards a particular entity may be associated with favour or disfavour toward reading. In line with these assumptions, in literature reading attitude is regarded to be a complex theoretical construct that is defined in various ways (Yamashita, 2004, p.1). Out of these definitions, the most cited one is stated by Alexander and Filler (1976) who describe reading attitude as a "a system of feelings related to reading which causes the learner to approach or avoid a reading situation" (Alexander and Filler, 1976, p.1). Whereas Alexander and Filler (1976) define reading attitude as a system of feelings, Smith (1990, p.215) describe it as "a state of mind, accompanied by feelings and emotions, that make reading more or less probable" (cited in Yamashita, 2004, p.1). Attitude towards reading is also regarded to be an emotional response, which 
is the primary reason most readers read and probably also the primary reason most non-readers do not read (Mathewson, 1994; cited in Marpaung 2020). It is assumed "that reading attitudes are largely the product of three factors: (a) beliefs about the outcomes of reading, judged in the light of how desirable an individual regards those outcomes, (b) beliefs about the expectations of others, judged in the light of the individual's motivation to conform to those expectations, and (c) specific reading experiences" (Mc Kenna, Stratton, Grindler, \& Jenkins, 1995, p.20).

Students' attitude toward reading is acknowledged as a central factor affecting reading performance (McKenna \& Kear, 1990). However, it is emphasized that the affective aspects of reading are "difficult to conceptualize, measure and address instructionally" (Mckenna \& Kear, 1990, p.626). Hence, researchers have tried to define components of reading attitude, which may allow a better understanding and a conceptualization of this term. "According to an extensive and in-depth review of literature by Reeves (2002), there is considerable agreement among contemporary researchers that reading attitude is defined by three components: cognitive (personal, evaluative beliefs), affective (feelings and emotions), and conative (action readiness and behavioral intentions)" (Yamashita, 2004, p.1).

A considerable amount of research has been undertaken to examine attitudes toward reading. Out of these researches, Yamashita (2004) investigated the relationship between both first language (L1) and second language (L2) reading attitudes, and learners' performance in L2 extensive reading.

Özönder (2015) examined prospective ELT students' foreign language reading attitudes and motivation. The study also examined the relationship between the participants' academic achievement and their attitudes and motivation in foreign language reading and the existence of any gender-related difference in the participants' reading attitudes and motivation. The results revealed that prospective ELT students have positive attitudes and motivation in foreign language reading. Also, there was a statistically significant positive correlation between academic achievement and attitudes and motivation in foreign language reading. The results indicated that there was no significant difference among groups regarding reading attitudes and motivation according to their academic achievement.

Akbari et al. (2017) explored the connection between L2 and L1 reading attitudes and the degree L2 reading attitude contributes to L2 reading achievement in the Iranian EFL context. Results showed that L1 and L2 reading attitudes highly correlated and L1 reading attitude significantly explained 51\% of the variance in L2 reading attitude, but between the L1 and L2 reading attitudes, only L2 reading attitude made a unique significant contribution to $\mathrm{L} 2$ reading achievement.

When research on reading attitude is examined, than it is evident that attitude towards reading is determined by various factors. "Past experiences related to reading, educational background, cultural belief, and success and failure in reading" (Day \& Bamford, 1998, cited in Akbari et al., 2017, p.1) are accepted to be among the factors, which have an impact on attitudes toward reading. Furthermore, it is pointed on the fact that different socio-cultural contexts may have an impact on reading attitude (Akbari et al., 2017). It is stated, "Attitudes are often affected by such factors as age, sex, family background, teaching methods and materials, reading habits and reading ability level" (Parker, 2004, p.2). It can be assumed that reading attitude may be affected also by these factors.

In this context, with this study, it is aimed to investigate Turkish foreign language teacher students' reading attitudes in view of the variables gender, major, education experience, and level of proficiency. Furthermore, it is aimed to examine to what extent the findings show similarities and diversities compared to findings in different socio-cultural educational contexts.

\subsection{Research questions}

This study is based on the following questions: 
1. How often do foreign language teacher students read and what are their language preferences for reading?

2. Does the reading attitude of foreign language teacher students differ in terms of the variable gender?

3. Does the reading attitude of foreign language teacher students differ in terms of the variable major?

4. Does the reading attitude of foreign language teacher students differ in terms of the variable education experience?

5. Does the reading attitude of foreign language teacher students differ in terms of the variable proficiency level?

\section{Method}

\subsection{Sample / Participants}

The participants of the study are 158 foreign language teacher students of an education faculty at a public university in Turkey. The groups were determined with the random sampling method. The data was collected during the academic year 2020 - 2021. Out of the participants, $32(20.3 \%)$ were at the preparatory class at the school of foreign languages. 139 (87.97\%) of the participants attended oneyear extensive language education at the preparatory class prior to their faculty education. Of the participants, 118 (74.7\%) were females and 40 (25.3\%) males. According to major, 66 (41.8\%) participants were in German language teaching and 92 (58.2\%) participants in English language teaching. According to the year of education, $32(20.3 \%)$ were at the preparatory class, $32(20.3 \%)$ were freshmen, 31 (19.6\%) sophomores, 32 (20.3\%) juniors, and 31 (\%19.6) seniors. The level of proficiency of $43(27.2 \%)$ participants was A, 87 (55.1\%) participants were on B and $28(17.7 \%)$ participants on $\mathrm{C}$ level.

\subsection{Instrument $(s)$}

In the study Reading Attitude Scale developed by Sarar Kuzu and Doğan (2015) is used. The scale is a five level Likert scale consisting of 38 items with three sub - categories. The sub - categories are named as 'contribution to individual and social development', 'interest and likes' and 'Considering it significant/ valuable'. The items were rated from 'strongly agree' (1) to 'strongly disagree' (5). Items $20,21,22,23,24,32$ and 33 were negatively worded items and reverse scored for the analysis. The reliability of the Reading Attitude Scale was found to be .95 (Sarar Kuzu \& Doğan, 2015). In this study, Cronbach's alpha value was found to be .87 , which indicates that the scale is reliable.

\subsection{Data collection and analysis}

The data was analysed by using PASW Statistics 18.00. The data showed normal distribution. Thus, the parametric statistical analyses independent - samples T test and One - Way ANOVA were used. In case of statistical significant differences in the One - Way ANOVA analysis results, the source of differentiation was examined with the Post Hoc Scheffe test.

\section{Results}

\subsection{Findings on Reading Frequency and Language Preference}

On the question "How often do you read texts in the German/ English language?" the answers are as following: 
Table 1. Reading frequency results regarding the department majored

\begin{tabular}{lrrrc}
\hline Frequency & \multicolumn{2}{c}{ German } & \multicolumn{3}{c}{ English } \\
\cline { 2 - 5 } & $\mathrm{N}$ & $\%$ & $\mathrm{~N}$ & $\%$ \\
\hline Daily & 17 & $(10.8 \%)$ & 59 & $(37.3 \%)$ \\
Twice a week & 14 & $(8.9 \%)$ & 21 & $(13.3 \%)$ \\
Three times a week & 16 & $(10.1 \%)$ & 18 & $(11.4 \%)$ \\
More frequent & 6 & $(3.8 \%)$ & 20 & $(12.7 \%)$ \\
Less frequent & 35 & $(22.2 \%)$ & 28 & $(17.7 \%)$ \\
Never & 70 & $(44.3 \%)$ & 12 & $(7.6 \%)$ \\
\hline
\end{tabular}

The findings on the reading frequency of foreign language teacher students revealed that most of the participants read less frequent $22.2 \%$ and never (44.3\%) in the German language. While most foreign language teacher students stated that they read daily $(37.3 \%)$, twice a week (13.3\%), three times a week (11.4\%), and more frequent (\%12.7) in English.

On the question "In which language do you prefer reading?" 9 (5.7\%) participants answered it as German, 45 (28.5\%) participants answered it as English, and 103 (65.2\%) participants answered it as Turkish.

\subsection{Findings on Descriptive Statistics of Reading Attitude}

In table 2 the findings of the descriptive statistics of reading attitude are presented.

Table 2. Descriptive statistics results of reading attitude

\begin{tabular}{lccccc}
\hline & $\mathrm{N}$ & Min & Max & Mean & Std. Deviation \\
\hline Personal and social development & 158 & 1.00 & 3.95 & 1.59 & .55 \\
Interest and likes & 158 & 1.29 & 4.07 & 2.27 & .40 \\
Significant/ Valuable & 158 & 1.00 & 5.00 & 2.32 & .80 \\
Reading Attitude & 158 & 1.11 & 3.84 & 1.94 & .39 \\
\hline
\end{tabular}

When the arithmetic average points are examined (Table 2), than it is evident that the highest average point is in the sub-category Significant/Valuable with 2.32 and the lowest average point in personal and social rationales. The arithmetic average point for reading attitude is found to be 2.21.

\subsection{Findings on Reading Strategies Use According to Gender}

T-Test was applied to determine the differences between the point averages of foreign language teacher students reading attitude in terms of the variable gender. 
Table 3. Results of the t-Test on reading attitude according to gender

\begin{tabular}{|c|c|c|c|c|c|c|}
\hline & \multirow[t]{2}{*}{ Gender } & \multirow[t]{2}{*}{$\mathrm{N}$} & \multirow[t]{2}{*}{$\overline{\mathrm{X}}$} & \multirow[t]{2}{*}{$\mathrm{Sd}$} & \multicolumn{2}{|c|}{ Level of importance } \\
\hline & & & & & $\mathrm{t}$ & $\mathrm{p}$ \\
\hline \multirow{2}{*}{$\begin{array}{l}\text { Personal and social } \\
\text { development }\end{array}$} & Female & 118 & 1.53 & .51 & -2.32 & $.024 *$ \\
\hline & Male & 40 & 1.78 & .62 & & \\
\hline \multirow[t]{2}{*}{ Interest and likes } & Female & 118 & 2.19 & .65 & -2.89 & $.005^{*}$ \\
\hline & Male & 40 & 2.51 & .58 & & \\
\hline \multirow[t]{2}{*}{ Significant/ Valuable } & Female & 118 & 2.26 & .80 & .73 & .090 \\
\hline & Male & 40 & 2.51 & .79 & & \\
\hline \multirow[t]{2}{*}{ Reading Attitude } & Female & 118 & 1.87 & .51 & -2.87 & $.005 *$ \\
\hline & Male & 40 & 2.14 & .53 & & \\
\hline
\end{tabular}

$* p<.05$

When Table 3 is examined, it is evident that the reading attitude average points of females has been found as ( $\overline{\mathrm{x}}=1.87)$ and males as $(\overline{\mathrm{x}}=2.14)$. In the comparison of point averages of the two groups, it is found that there are significant differences between the two groups $* \mathrm{p}<.05$ level $(\mathrm{p}=.005)$. Males had on average a higher reading attitude average point compared to females.

Also in the sub - categories personal and social development and interest and likes are significant differences in view of gender. Reading attitude in the sub - category personal and social development show significant differences in terms of gender at $* p<.05$ level $(p=.024)$. When average points are examined, than it is evident that the average points of males $(\bar{x}=1.78)$ are higher than females $(\bar{x}$ $=1.53$ ). Also in the sub - category interest and likes, the average points of males ( $\bar{x}=2.51)$ are higher than females $(\overline{\mathrm{x}}=2.19)$, indicating that males have a positive reading attitude when compared to females in the sub - category interest and likes.

\subsection{Findings on Reading Attitude According to Major}

T-Test was applied to determine the differences between the point averages of foreign language teacher students' reading attitude in terms of the variable major.

Table 4. Results of the independent samples t-Test on reading attitude according to major

\begin{tabular}{|c|c|c|c|c|c|c|}
\hline & \multirow[t]{2}{*}{ Major } & \multirow[t]{2}{*}{$\mathrm{N}$} & \multirow[t]{2}{*}{$\overline{\mathrm{X}}$} & \multirow[t]{2}{*}{$\mathrm{Sd}$} & \multicolumn{2}{|c|}{ Level of importance } \\
\hline & & & & & $\mathrm{t}$ & $\mathrm{p}$ \\
\hline \multirow[t]{2}{*}{ Personal and social development } & German & 66 & 1.42 & .42 & -3.68 & $.000^{*}$ \\
\hline & English & 92 & 1.72 & .60 & & \\
\hline \multirow[t]{2}{*}{ Interest and likes } & German & 66 & 2.19 & .64 & -1.31 & .191 \\
\hline & English & 92 & 2.33 & .64 & & \\
\hline \multirow[t]{2}{*}{ Significant/ Valuable } & German & 66 & 2.17 & .71 & -2.02 & $.044^{*}$ \\
\hline & English & 92 & 2.43 & .85 & & \\
\hline \multirow[t]{2}{*}{ Reading Attitude } & German & 66 & 1.80 & .45 & -2.81 & $.006^{*}$ \\
\hline & English & 92 & 2.04 & .56 & & \\
\hline
\end{tabular}

$* \mathrm{p}<.05$ 
When table 4 is examined, than it can be seen that reading attitude differs in terms of the variable major at $* \mathrm{p}<.05$ level $(\mathrm{p}=.006)$. The average points of English language teacher students $(\overline{\mathrm{x}}=2.04)$ are higher than German language teacher students' average points $(\bar{x}=1.80)$. Significant differences are also in the sub - categories personal and social development and significant and valuable. In the sub-category personal and social development the significant difference $\left({ }^{*} p<.05 ; p=.000\right)$ is caused by the average points of English language teacher students, which are higher $(\bar{x}=1.72)$ than German language teacher students $(\overline{\mathrm{x}}=1.42)$. Also in the sub-category significant and valuable this differentiation is evident. English language teacher students have higher average points $(\overline{\mathrm{x}}=2.43)$ than German language teacher students ( $\overline{\mathrm{x}}=2.17$ ).

\subsection{Findings on Reading Attitude According to Education Experience}

One - Way ANOVA was applied to determine the differences between the point averages of the reading attitude in terms of the variable education experience.

Table 5. Results of the variance analysis on reading attitude according to the education experience

\begin{tabular}{|c|c|c|c|c|c|c|}
\hline & Source of Variance & df & $\begin{array}{l}\text { Sum of } \\
\text { Squares }\end{array}$ & $\begin{array}{l}\text { Mean } \\
\text { Square }\end{array}$ & $\mathrm{F}$ & $\mathrm{p}$ \\
\hline \multirow{4}{*}{$\begin{array}{l}\text { Personal and social } \\
\text { development }\end{array}$} & Between Groups & 4 & 5.179 & 1.295 & 4.67 & $.001 *$ \\
\hline & Within Groups & 153 & 42.369 & .277 & & \\
\hline & Total & 157 & 47.548 & & & \\
\hline & Between Groups & 4 & 3.759 & .940 & 2.331 & .058 \\
\hline \multirow[t]{2}{*}{ Interest and likes } & Within Groups & 153 & 61.671 & .403 & & \\
\hline & Total & 157 & 65.430 & & & \\
\hline \multirow[t]{3}{*}{ Significant/Valuable } & Between Groups & 4 & 6.342 & 1.586 & 2.556 & $.041 *$ \\
\hline & Within Groups & 153 & 94.906 & .620 & & \\
\hline & Total & 157 & 101.249 & & & \\
\hline \multirow[t]{3}{*}{ Reading Attitude } & Between Groups & 4 & 4.035 & 1.009 & 3.903 & $.005 *$ \\
\hline & Within Groups & 153 & 39.543 & .258 & & \\
\hline & Total & 157 & 43.578 & & & \\
\hline
\end{tabular}

$* \mathrm{p}<.05$

When Table 5 is examined, it can be seen that there is a significant differentiation at $* \mathrm{p}<.05$ level $(p=.005)$ of foreign language teacher students' reading attitude average points in terms of the variable education experience. Post-Hoc Scheffe test was applied to find out between which groups this differentiation is. Post-Hoc Scheffe test results show that there are significant differences between the foreign language teacher students in the preparatory class and seniors. Seniors had higher average points compared to foreign language teacher students in the preparatory class.

Also in the sub - category personal and social development there were significant differences ( $\mathrm{F}$ $=4.67, \mathrm{p}=.001$ ) between the groups. Post-Hoc Scheffe test was applied to find out between which groups this differentiation is. Post-Hoc Scheffe test results reveal that in the sub - category personal and social development significant differences are between preparatory class students and sophomores and seniors. Sophomores and seniors mean differences are higher than of preparatory class students. 
Variance analysis results on reading attitude in the sub - category Significant/ Valuable indicate significant differences between the groups $(\mathrm{F}=2.556, \mathrm{p}=.041)$. Post-Hoc Scheffe test results show that the reason for this difference is caused by the mean differences between preparatory class students and freshmen. Freshmen had higher average points as preparatory class students.

\subsection{Findings on Attitude According to Level of Proficiency}

One - Way ANOVA was applied to determine the differences between the point averages of reading attitude in terms of the variable level of proficiency.

Table 6. Results of the variance analysis on reading attitude according to the level of proficiency

\begin{tabular}{|c|c|c|c|c|c|c|}
\hline & $\begin{array}{l}\text { Source of } \\
\text { Variance }\end{array}$ & df & $\begin{array}{l}\text { Sum of } \\
\text { Squares }\end{array}$ & $\begin{array}{l}\text { Mean } \\
\text { Square }\end{array}$ & $\mathrm{F}$ & $\mathrm{p}$ \\
\hline \multirow{4}{*}{$\begin{array}{l}\text { Personal and social } \\
\text { development }\end{array}$} & Between Groups & 2 & 2.002 & 1.001 & 3.406 & $.036 *$ \\
\hline & Within Groups & 155 & 45.546 & .294 & & \\
\hline & Total & 157 & 47.548 & & & \\
\hline & Between Groups & 2 & .486 & .243 & .580 & .561 \\
\hline \multirow[t]{2}{*}{ Interest and likes } & Within Groups & 155 & 64.944 & .419 & & \\
\hline & Total & 157 & 65.430 & & & \\
\hline \multirow[t]{3}{*}{ Significant/ Valuable } & Between Groups & 2 & 2.849 & 1.425 & 2.244 & .109 \\
\hline & Within Groups & 155 & 98.399 & .635 & & \\
\hline & Total & 157 & 101.249 & & & \\
\hline \multirow[t]{3}{*}{ Reading Attitude } & Between Groups & 2 & 1.404 & .702 & 2.580 & $.079 *$ \\
\hline & Within Groups & 155 & 42.173 & .272 & & \\
\hline & Total & 157 & 43.578 & & & \\
\hline
\end{tabular}

$* \mathrm{p}<.05$

When Table 6 is examined, it can be seen that there is not a significant of language teacher students' reading attitude average points in terms of the level of proficiency ( $\mathrm{F}=2.580 ; \mathrm{p}=.079)$. But there are significant differences in the sub-category personal and social development $(\mathrm{F}=3.406$; $\mathrm{p}=.036$ ). Post-Hoc Scheffe test results show that this differentiation is caused by language teacher students on the $\mathrm{C}$ level, who have higher average points than compared to language teacher students on an A level.

\section{Discussion}

The aim of this study was to examine language teacher students' reading attitudes. The findings of this study revealed that foreign language teacher students read fewer texts in German as in English. Moreover, $44.3 \%$ of foreign language teacher students stated that they never read texts in German. Whereas $37.3 \%$ of the foreign language teacher students stated that they read daily texts in English. Nevertheless, the language preference for reading was of $65.2 \%$ participants Turkish. Only $5.7 \%$ of the foreign language teacher students preferred German and 28.5\% participants English. It is evident that the majority of the foreign language teacher students preferred more to read texts in Turkish as in a foreign language. This finding is consistent with the findings of the study conducted by Genç (1995), 
where $77 \%$ of German language teacher students preferred reading texts in the Turkish language more as in German. Yet, for the development of linguistic skills, it is important to get comprehensible input through reading (Krashen, 2007). Moreover, it is emphasized that extracurricular reading favours achievement in a foreign language learning (Krashen, 1997).

When the results on foreign language teacher students' reading attitude in terms of gender are analysed, it is evident that males have a higher mean average as females. This is also evident in the categories of personal and social development and interest and likes. But in the category 'significant and valuable' there were no significant differences of reading attitude in terms of gender. When this finding is compared with research findings of other studies than it is evident that the results are in line with the study conducted by Marpaung and Sihombing (2020), but not consistent with the research findings conducted by Şentürk (2015) who investigated EFL Turkish university students' attitudes towards reading in English and found that there were no significant differences between males and females. This inconsistency may be based on using different measurement instruments for the determination of reading attitude. Diverse sub-categories may cause differences in attitudes towards reading in terms of gender. Marpaung and Sihombing (2020) used the "Attitude Scale Towards Reading Habit" developed by Gömleksiz (2014) to investigate the reading attitude of English department students. The scale consists of six sub-categories: Love, habit, need, necessity, desire, effect, and utility. Şentürk (2015) used the Foreign Language Reading Attitudes and Motivation Scale developed by Erten, Topkaya, and Karakaş (2010). The scale consisted of four sub-categories: Intrinsic value of reading, reading efficacy, the extrinsic value of reading, and foreign language linguistic utility. Whereas in the present study Reading Attitude Scale developed by Sarar Kuzu and Doğan (2015) is used, which consists of three sub-categories: 'contribution to individual and social development', 'interest and likes' and 'Considering it significant/ valuable'. It can be assumed that the participants of the studies may have rated the items of the sub-categories differently, which means that reading attitudes in diverse sub-categories may lead to differences of reading attitudes in terms of gender. But, as like there are various definitions and approaches towards reading attitude and its definition, this variety seems also to be evident in the scales developed to determine reading attitude. In this context, it can be suggested to develop scales for the determination of reading attitude in a foreign language, while considering diverse sub- categories.

The results on foreign language teacher students' reading attitude in terms of major revealed that reading attitude differs according to major. English language teacher students' have a higher mean average compared to German language teacher students'. However, in the category interest and likes, there were no significant differences. This result may be an evidence for a positive correlation between the reading preference and reading attitude. Nevertheless, as abovementioned the students preferred to read text much more in English as in the German language. Hence, to read more in the target language may influence attitude towards reading.

The results on education experience showed that there were significant differences of foreign language teacher students' reading attitudes. Seniors had higher mean points compared to foreign language teacher students of the preparatory class. But, there were no significant differences in the category interest and likes. The higher mean points of more experienced students may be explained with being superior in experiencing reading in the foreign language. In literature, these finding is mostly explained with the Matthew Effects in reading, which is based on the hypotheses, which explains how the mechanism operates to create rich-get-richer and poor-get-poorer patterns of reading achievement (Stanovich, 1986). It is assumed that there is a reciprocal relationship of a causal connection of cognitive development and reading achievement. With other words, the more someone reads, the more he develops reading ability. The impact of extensive reading to students reading ability may also have its root on this assumption. It is therefore suggested to support students with extensive 
reading. However, reading should be pleasant and not lead students suffering. Nevertheless, according to Krashen's (2006) Pleasure Hypothesis reading is more effective when it is felt enjoyable and pleasant. It is furthermore stated, "Those who discover reading in a second language clearly find it pleasant when they can find interesting and comprehensible reading material" (Krashen, 2006, p.2). In-school free reading, self-selected voluntary reading, and self-selected recreational reading is among suggested reading activities, which may ensure a pleasant reading environment (Krashen, 2006).

When the results on foreign language teacher students' reading attitude in terms of the level of proficiency are examined, it is evident that there were no significant differences in total. But in the category of personal and social development, there were significant differences in terms of the level of proficiency. Foreign language teacher students on the $\mathrm{C}$ level had higher mean points compared to students on the A level. This finding is in line with the research findings conducted by Şentürk (2015), which indicates that high proficiency learners have a positive attitude towards reading compared to lower ones. Reading in a foreign language is a more sophisticated process as to read in L1. Researchers have argued that reading ability in a second language may appear to be largely a function of proficiency in that language (Carrell, 1991). Attitude towards reading in the foreign language may have its basis on this assumption.

\section{Conclusions}

Reading attitude plays a key role in the development of reading skills. Thus, in foreign language education, it is of great importance that learners possess positive attitudes towards reading in order to develop reading skills in a foreign language accordingly. In literature, it is pointed on the fact that learners get more involved in reading when the reading materials are easily available and apply to their interests. It is stated that “ (...) "light reading” is a conduit to heavier reading” (Krashen, 1997, p.13). In this regard, comics, magazines, and newspapers are among texts, which are described as a kind of "light reading" material (Krashen, 1997). Nowadays, these kinds of texts are also easily available on the Internet. It is important to give impulse to students how to get access to these materials, while considering their proficiency level and their personal preferences. In literature, it is pointed out that there are evidences, which suggests that there are personal attributes and environmental factors that influence the attitudes toward reading (Parker, 2004, p.9). As the research findings revealed that foreign language teacher students' reading attitude differs in terms of the variables gender, major and education experience. These factors may also be among factors, which influence reading attitude in a foreign language. Based on the study findings, it can be suggested to consider learners' diverse reading attitudes and to support them accordingly in developing positive attitudes towards reading in the foreign language. Promoting students to read in the foreign language may influence their achievement not just in reading, but also linguistically.

\section{References}

Akbari, H., Ghonsooly, B., Ghazanfari, M., \& Shahriari, H. (2017). Attitude toward reading: L1 or L2 or both. SAGE Open, 1-10. https://doi.org/10.1177/2158244017717303

Alexander, J. E. \& Filler, R. C. (1976). Attitudes and reading. Newark, DE: International Reading Association.

Alkhannani, B. (2016). An exploration of the educational experiences of gifted English language learners in the Saudi context. (Unpublished Doctoral thesis.) School of education, College of Social Sciences, University of Glasgow. 
Bastug, M. (2014). The structural relationship of reading attitude, reading comprehension and academic achievement. International Journal of Social Sciences and Education, 4(4), 931-946

Carrell, P. (1991). Second language reading: Reading ability or language proficiency? Applied Linguistics, 12(2), 159-179. https://doi.org/10.1093/applin/12.2.159

Eagly, A. H. \& Chaiken, S. (1993). The psychology of attitude. New Jork: Harcourt Brace Jovanovich College Publishers.

Erten, I. H., Topkaya, Z. E., \& Karakaş, M. (2010). Exploring motivational constructs in foreign language reading. Hacettepe University Journal of Education, 39, 185 -196.

Genç, A. (1995). Yabancı dilde okuma alışkanlığı. Hacettepe Üniversitesi Eğitim Fakültesi Dergisi, 11(11), 71- 74 .

Gömleksiz, M. N. (2014). Kitap okuma alışkanlığına ilişkin bir tutum ölçeğinin geçerlik vegüvenirliği. Fırat Üniversitesi Sosyal Bilimler Dergisi, 2(14), 185-195.

Krashen, S. (1997). Free voluntary reading: it works for first language, second language and foreign language acquisition. MEXTESOL Journal, 20(3), 11- 18.

Krashen, S. (2006). Pleasure reading. Young Learners SIG, 1-4.

Krashen, S. (2007). Extensive reading in English as a foreign language by adolescents and young adults: A meta-analysis. International Journal of Foreign Language Teaching, 3(2), 23-29.

Marpaung, M. Br. \& Sihombing, H. B. (2020). The attitude towards reading of English department students in Darma Agung University. Jurnal Littera, 1(1), 46-58.

McKenna, M. C. \& Kear, D. J. (1990). Measuring attitude toward reading: A new tool for teachers. The Reading Teacher, 43(9), 626-639.

McKenna, M.C., Kear, D.J., \& Ellsworth, R.A. (1995). Children's attitudes toward reading: A national survey. Reading Research Quarterly, 30(4), 934-956. https://doi.org/10.2307/748205

McKenna, M. C.; Stratton, B. D., Grindler, M. C., \& Jenkins, S. J. (1995). Differential effects of whole language and traditional instruction on reading attitudes. Journal of Reading Behavior, 27(1), 19-44. https://doi.org/10.1080/10862969509547867

Sarar Kuzu, T. \& Doğan, T. (2015). Öğretmen adaylarına yönelik okuma tutum ölçeği geliştirme. Turkish Studies, 10(5), 771-786. http://doi.org/10.7827/TurkishStudies.8938

Smith, A. N. (1971). The importance of attitude in foreign language learning. The Modern language Journal, 55(2), 82-88. https://doi.org/10.2307/321854

Stanovich, K. E. (1986). Matthew effects in reading: Some consequences of individual differences in the acquisition of literacy. Reading Research Quarterly, XXI(4), 360 - 407.

Özönder, Ö. (2015). Prospective ELT students' foreign language reading attitudes and motivation. $\begin{array}{lllll}\text { Procedia - Social and Behavioral } & \text { Sciences, } & 199, & \text { 722-729. }\end{array}$ https://doi.org/10.1016/j.sbspro.2012.07.603

Yamashita, J. (2004). Reading attitudes in L1 and L2, and their influence on L2 extensive reading. Reading in a Foreign Language, 16(1), 1-19. 


\section{AUTHOR BIODATA}

Aysel Deregözü is an instructor at School of Foreign Languages of Inonu University. She has received her Ph.D. degree in German Language Teaching from Marmara University. Language teaching methods, language teacher education, language teacher competencies are among her fields of interest.

Bilal Üstün is an instructor at School of Foreign Languages of Nevşehir Hacı Bektaş Veli University. He received his Ph.D. degree in German Language Teaching from Anadolu University. Linguistics, migration, language teaching methods are among his fields of interest. 